\title{
Building inside air temperature parametric study
}

\section{Параметрический анализ внутренней температуры воздуха здания}

\author{
I.Yu. Bilous, \\ V.I. Deshko, \\ I. O. Sukhodub, \\ National Technical University of Ukraine Kiev \\ Polytechnic Institute, Kiev. Ukraine
}

Key words: energy efficiency; modeling; heating rate; air exchange; inside air temperature; climatic data; regression

\author{
Ассистент И.Ю. Белоус, \\ д-р техн. наук, проф., зав. каф В.И. Дешко, \\ канд. техн. наук, доцент И.О. Суходуб, \\ Национальный технический университет \\ Украины Киевский политехнический \\ институт, г. Киев, Украина
}

\begin{abstract}
Ключевые слова: энергоэффективность; моделирование; уровень отопления; воздухообмен; внутренняя температура; климатические данные; регрессия
\end{abstract}

\begin{abstract}
Nowadays energy resources saving problem is extremely important, especially for heating in buildings. The aim of the paper is to simulate indoor air temperature depending on heating rate, solar heat gains, infiltration rate and outdoor air temperature. In order to get the desired result dynamic model of the room was created in EnergyPlus program, which is a widely used building energy simulation program. Based on the developed model and modified IWEC weather data the series of simulations were performed for inside air temperature calculation depending on internal and external factors changes. The analysis of individual and aggregate factors influence on inside air temperature change is performed. The multiple linear regression model structure is analysed and background of factors change over the past three days is chosen. Regression models for daily average inside air temperature dependence on each of the factors and all of them are created. Results verification is performed for prognosis values of temperature in comparison with simulation for December weather data from IWEC. Regression models can be used for complex analysis of problems connected with selecting heating rate, influence assessment of climatic conditions on indoor air temperature, qualitative and quantitative heating system regulation.
\end{abstract}

Аннотация. В настоящее время проблема экономии энергоресурсов очень актуальна, особенно с точки зрения потребления на отопление зданий. Целью работы является моделирование изменения внутренней температуры воздуха в зависимости от уровня отопления, солнечных теплопоступлений, инфильтрации и наружной температуры. Для достижения поставленной цели была разработана динамическая модель комнаты в программном продукте EnergyPlus, широко используемом для энергетического моделирования зданий. На основе математической модели и модификации погодных данных IWEC проведен ряд имитационных моделирований внутренней температуры воздуха в зависимости от изменения внутренних и внешних фракторов. Рассмотрено индивидуальное и совместное влияние выбранных фракторов на изменение температуры воздуха во времени. Проведен анализ и выбрана структура многофакторной линейной регрессии для определения влияния предыстории изменения фракторов. Построены регрессионные зависимости внутренней температуры воздуха для каждого из фракторов и регрессионная модель для совместного влияния факторов. Проведена верификация полученных результатов по внутренней температуре на базе регрессионного анализа в сравнении с данными имитационного моделирования для декабря с данных IWEC. Регрессионные зависимости могут быть использованы при комплексном подходе к решению задач, связанных с подбором уровня отопления, оценке влияния климатических фракторов на внутреннюю температуру воздуха, качественным и количественным регулированием систем отопления.

\section{Introduction}

Anthropogenic climate change really entered the arena of a broad experts review. Impact assessment of various aspects of social life, including building energy consumption, indoor air quality, and overall building energy performance, on climate change is of great importance. Also, today the problem of energy resources saving is extremely important for Ukraine. According to the data obtained 
from [1] energy consumption for buildings operation is about $2.3 \mathrm{GJ} /$ year, and this is more than $25 \%$ in the energy balance of Ukraine. A large proportion of building energy consumption accounts for heating. Heating system qualitative adjustment depending on changes in internal and external parameters allows to improve comfortable indoor conditions and to achieve energy savings during heating period.

There are different methods that are used for building energy efficiency assessment. The research works of V.N. Bogoslovskij and Ju.A. Tabunschikov made a significant contribution to development of mathematical models for buildings energy performance system analysis, the implementation of which requires the creation/availability of special software platforms [2, 3].

The most simple and commonly used method to calculate energy consumption for heating is based on heating degree-days [4]. Fixed duration of heating period is needed for heat transfer losses and heat gains calculation.

However, this method can over evaluate the energy consumption for heating because of not taking into consideration building thermal inertia. Other method based on EN ISO 13790 [5] can use hourly (5R1C model) or monthly time periods for calculation in order to take into account building thermal mass. There are some modifications of simplified hourly model, for example 6R1C, that divide ventilation into controlled and uncontrolled (infiltration) parts and provide optional equations for different HVAC systems [6].

CFD software packages can be used to perform more detailed investigate heat and mass transfer processes in buildings in steady-state and transient modes [7]. It can be used to assess influence of external and internal factors on thermal state of the space, local ventilation characteristics, thermal comfort etc. Although, the calculation of unsteady-state heat and mass transfer processes in buildings using CFD packages can be quite a challenge.

One of the most convenient and precise way to investigate energy efficiency and thermal state of buildings is to use whole building energy simulation programs as EnergyPlus, DOE-2, eQuest, TRNSYS etc. [8]. Some researches compare real energy consumption with data obtained from different building simulation programs $[9,10]$, others compare different software in terms of results accuracy and convenience of use [11-13].

EnergyPlus is a widely used building energy simulation program that includes modules for zones thermal balance and HVAC equipment analysis [14]. EnergyPlus was created on basis of DOE-2, BLAST, which makes it attractive for use due to the accuracy of simulation results $[15,16]$, that were compared with actual building energy consumption [17-19].

It can be used for detailed simulation of convective and radiant heat transfer, infiltration and natural ventilation, solar and internal heat gains etc. EnergyPlus uses the Window 5 program for heat transfer calculation through windows and glazed doors [20] that considers layer by layer input of glazing system with different optical properties on front and back side of the glass, the angles of radiation incidence and reflection, heat balance iterative calculation for glass surface temperature determination, heat transfer through frame and dividers, the impact of internal and external shading devices etc. EnergyPlus considers one dimensional heat transfer through building envelope, therefore thermal bridges effect [21] is not calculated explicitly. In order to account for thermal bridges effect heat transfer coefficients for building envelope constructions can be modified. EnergyPlus is based on an integrated approach of heat and mass balance and technical building systems calculation that results in more accurate estimation of indoor air temperature. Some of the papers propose to use predetermined from dynamic simulation "normalized energy consumption coefficients" in combination with monthly energy bills in order to obtain the hourly distribution of energy consumption for typical buildings [22].

Using of dynamic modelling is complex and time consuming. That is why empirical modelling techniques using neural network [23], fuzzy logic [24, 25] and regression analysis are recently becoming widespread. Creating regression models are adequate alternative to complex building modelling and tool for heat consumption forecasting, ensuring adequate indoor comfort conditions. Regression models which allow analyzing and predicting the behaviour of various aspects of the building as an energy system can be based on actual data of energy consumption and factors that influence it [26-29]. For example, monitoring of indoor air temperature in the space allows building regression models for indoors temperature prediction based on external and internal factors [30]. Also regression based models can be used for analysis of heat consumption regulation efficiency including heat source (qualitative) and consumer (qualitative) [31-33]. But sometimes it is difficult to get the actual values of all influencing factors or it is not possible to assess a single influence of factors on indoor temperature. That is why other researchers use building simulation models to produce data for regression analysis [34-36].

Bilous I.Yu., Deshko V.I., Sukhodub I.O. Building inside air temperature parametric study. Magazine of Civil Engineering. 2016. No. 8. Pp. 65-75. doi: 10.5862/MCE.68.7 
Created regression models allow describing the indoor air temperature and energy consumption with sufficient accuracy. Also its usage is not so complex and time consuming as actual building simulation. But it has some limitations, it can be used only within the applied range of influencing factors, also models were created for climatic conditions in different countries.

The aim of the paper is to simulate indoor air temperature depending on heating rate, solar heat gains, infiltration rate and outdoor air temperature. In order to get the desired result following tasks were addressed: room model creation in EnergyPlus; investigation of different factors impact on the internal temperature; creation of multi-regression models to assess the individual and cumulative effect of selected factors.

\section{Methods \\ Model description}

Dynamic model of a room was created in EnergyPlus software for indoor air temperature investigation. Created model can be used for different objectives: calculation of heating and cooling load for design conditions under determined inside temperature; defining energy consumption for longer periods, for example, annual calculation; indoor air temperature calculation based on energy balance of the zone, including heat losses, heating rate, solar and internal heat gains. The last one can help to investigate the influence of building envelope thermal resistance, internal and external factors on temperature conditions inside the room for high-quality regulation of heating system. Level of solar heat gains can be adjusted by different types of shading devices and special glass coating [16].

Mathematical model in EnergyPlus program takes into account diffuse and direct solar radiation (using direct normal radiation) for solar heat gains calculation through windows and opaque building elements.

The object of investigation is a room with one outside wall with window, tree interior walls, interior ceiling and floor. Room floor and ceiling size is $5.5 \times 6.1 \mathrm{~m}$, floor-to-ceiling height is $3.2 \mathrm{~m}$. The dimensions of exterior wall are $5.5 \times 3.2 \mathrm{~m}$, exterior window is $5 \times 2.5 \mathrm{~m}$. The design of the building meets the requirements of the building construction of 1970 s that accounts for $80-90 \%$ of existing buildings in Ukraine. Regardless of the current normative value of thermal resistance $3.3\left(\mathrm{~m}^{2} \cdot \mathrm{K}\right) / \mathrm{W}$ the existing outer wall has the thermal resistance $R=1\left(\mathrm{~m}^{2} \cdot \mathrm{K}\right) / \mathrm{W}$. The outer window is double glazed system with wooden frame. It has no interior or exterior shading devices. Interior walls have and are built with half-brick $(\delta=0.125 \mathrm{~m})$. Ceiling and floor is reinforced concrete slab $(\delta=0.2 \mathrm{~m})$. Ventilation is natural. Model input parameters are hourly climatic data from IWEC file (International Weather for Energy Calculation), that include dry-bulb temperature, relative humidity, atmospheric pressure, wind speed and direction, direct and diffuse solar radiation etc. Also, heating level, infiltration rate, floor number and building orientation can be changed.

\section{Conditions of model functioning}

Inside air temperature is dependent on number of factors. EnergyPlus takes into account the following ones: outside air temperature, direct and diffuse solar radiation, wind pressure, wind speed and direction, humidity, internal heat gains from people, electric appliances and lightning, heating rate, air exchange rate etc Outside air temperature, solar heat gains, infiltration rate and heating rate were chosen as the most influencing ones for the analysis of existing buildings based on the previous research data. The main objective of dynamic modelling is to investigate the change of indoor air temperature due to disturbances of each influencing factors and their consistency in the given range. Ten minute time intervals were used in heat balance calculation in EnergyPlus. After the stabilisation of indoor air temperature profile one of the factors value was changed and its influence on indoor air temperature conditions was analyzed.

Weather conditions of typical December day were selected as base from IWEC file for Kiev, Ukraine. Temperature conditions of the selected day are close to the climatic data from [37] (fig. 1). Daily fluctuations in outside air temperature ( $\mathrm{t}_{0}$ ) in December for Kiev are in the range of $0 \ldots-5^{\circ} \mathrm{C}$. 


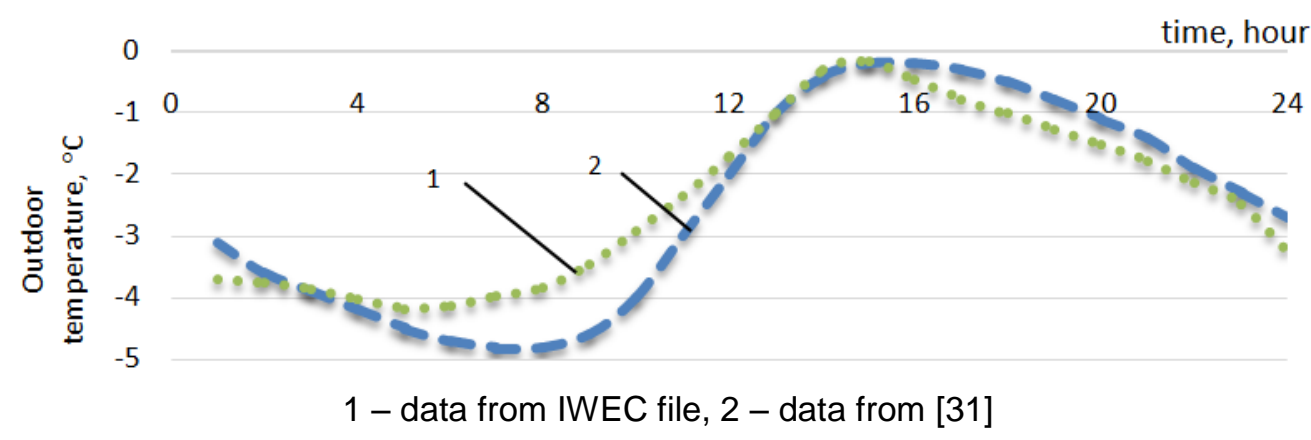

Figure 1 - Daily changes in outdoor air temperature for December typical day

Peak value of global solar radiation on horizontal surface is $115 \mathrm{~W} / \mathrm{m}^{2}$ for cloudy December day from IWEC file data. According to climatic data from [37] its average daily value is $22 \mathrm{~W} / \mathrm{m}^{2}$. Selected base values for diffuse and direct normal radiation provide the magnitude of solar heat gains through exterior window with southern and northern cardinal direction in the range $0 \ldots 600 \mathrm{~W}$ and $0 \ldots 325 \mathrm{~W}$ respectively (fig. 2). Wind speed was set to $2.7 \mathrm{~m} / \mathrm{s}$ with prevailing western direction [38]. For the base calculation air changes per hour was set to 1 hour $^{-1}$. The heating rates for base external conditions were selected taking into account the room orientation (southern or northern) and were 1300 and $1365 \mathrm{~W}$ respectively, that accounts for 62 and $65 \%$ of design heating rate $(2100 \mathrm{~W})$. Given base input values provide average daily value for indoor air temperature $t_{\text {in }}=18 \stackrel{\circ}{\mathrm{C}}$ after stabilisation.

Base climatic data were introduced in modified IWEC file. Initial calculations show that daily fluctuation of indoor air temperatures become stable on the $20^{\text {th }}$ day provided that daily average base parameters are constant. Using the modifications of IWEC weather file influencing factors are changed alternately. Disturbances of external temperature daily fluctuations correspond to the daily average change value in the range $\Delta t_{\text {out }}=[3 \ldots+3]^{\circ} \mathrm{C}$. Amplitude of fluctuations remained the same as in Figure 1. For the overall heating period in Kiev maximum between-day outside air temperature fluctuations is 6 $10^{\circ} \mathrm{C}$. Average between-day temperature fluctuations are $3-4^{\circ} \mathrm{C}$ based on weather data from IWEC file.

Although the model uses solar radiation data from IWEC file, that include diffuse horizontal and direct normal radiation, the resulting solar heat gains through the window are taken for the analysis of solar radiation impact on indoor air temperature. Disturbances of solar heat gains (fig. 2) were set by changing the daily fluctuations of direct solar radiation, thus taking into account room orientation. EnergyPlus calculates the value of direct solar heat gains through direct normal radiation value. The maximum daily fluctuations of direct normal radiation were changed in the range of $0 \ldots 600 \mathrm{~W} / \mathrm{m}^{2}$ in increments of $200 \mathrm{~W} / \mathrm{m}^{2}$, leaving the same daily behaviour characteristics. This range corresponds to heating period conditions. Fluctuations rate of daily diffuse solar radiation is in the range of $0 \ldots 100 \mathrm{~W} / \mathrm{m}^{2}$ and is not changed. Solar activity disturbances were simulated for the duration of one day and three days.

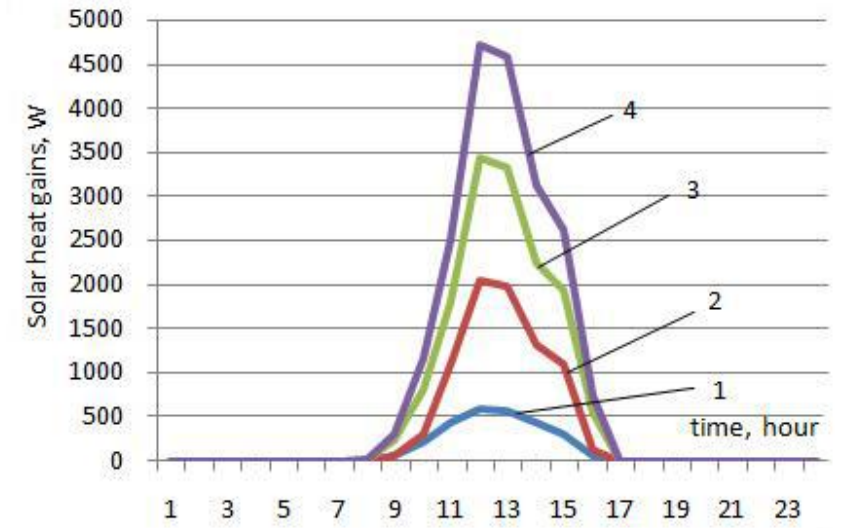

a)

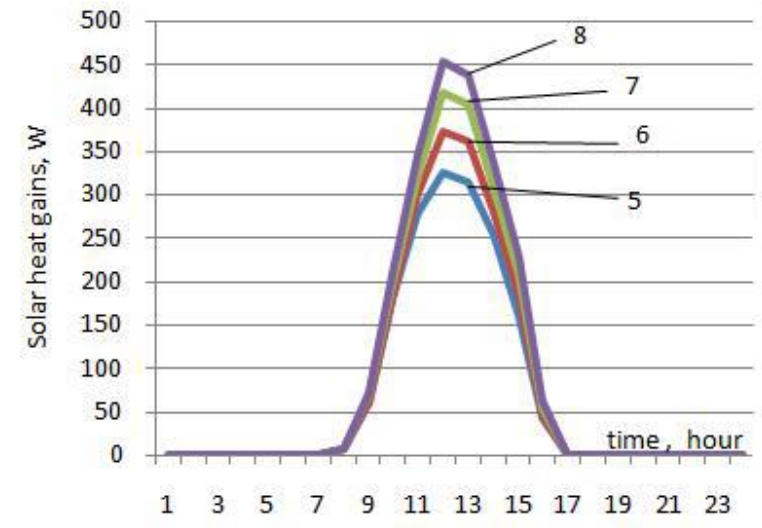

b)

Figure 2. Zone solar heat gains through the window for the southern (a) and northern (b) side of the building: Daily average solar heat gains: 1-119 W (base), 2-344 W, 3-608 W, 4-827 W, 5- $67 \mathrm{~W}$ (base), 6- $73 \mathrm{~W}, 7-81 \mathrm{~W}, 8-87 \mathrm{~W}$

The disturbances range of infiltration (air changes per hour) for the zone was $0.5 \ldots 1.5$ hour $^{-1}$. This range is chosen taking into account the influence of internal and external air temperature difference,

Bilous I.Yu., Deshko V.I., Sukhodub I.O. Building inside air temperature parametric study. Magazine of Civil Engineering. 2016. No. 8. Pp. 65-75. doi: 10.5862/MCE.68.7 
number of storeys, wind speed and direction [39]. Heating rate disturbances values are set to $45-85 \%$ from design value.

\section{Results and discussions}

\section{The influence of influencing factors on the indoor air temperature}

The zone with considered thermal properties of building enclosures comes to stationary mode within an average period of 20 days provided that external and internal parameters are constant (fig. 3). That is why the disturbance of each influencing factor was set on the $20^{\text {th }}$ day and changes in internal temperature behaviour were investigated. It is difficult to determine the weight/influence of each of the selected factors under the combined influence of external factors on the internal temperature and predict the behaviour of a building system with other combinations of disturbances. In order to determine the individual impact of factors each of them is examined in turn.

Daily fluctuations of southern oriented room inside air temperature for 1-day and 3-day disturbances of solar radiation are shown in Figure 3. Daily maximum temperature is increased by $2-6{ }^{\circ} \mathrm{C}$, depending on the level of disturbance. For the room with outside window oriented to the north daily fluctuations of the internal temperature barely changed. After 1-day solar radiation disturbance the considerable remaining effect lasts for 5-6 days, for 3-day disturbance it can last for 10 days approximately.

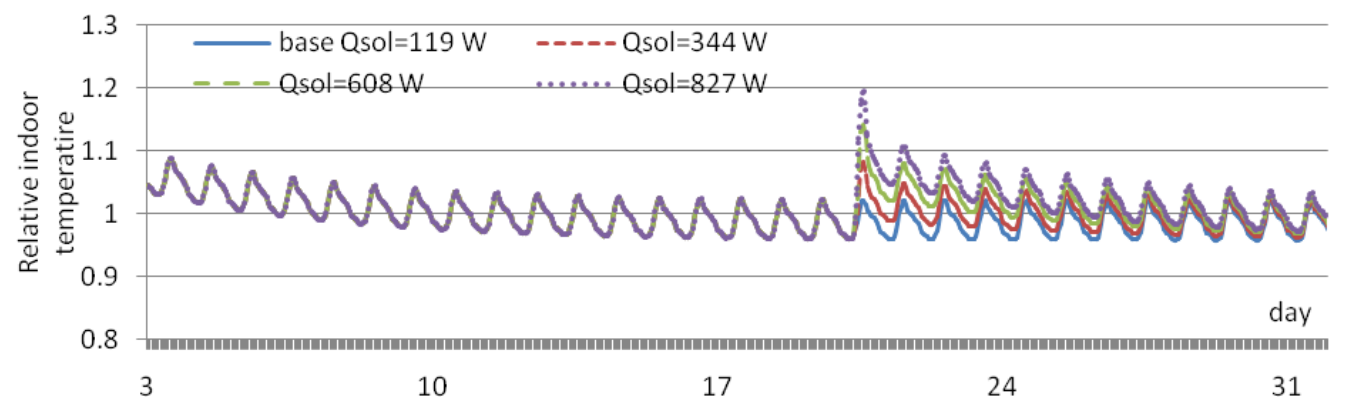

a)

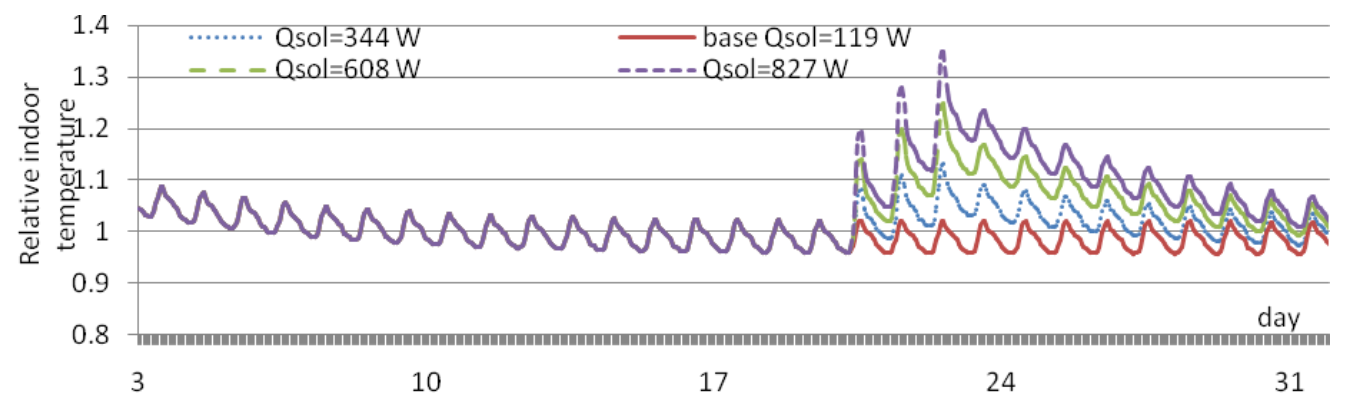

b)

Figure 3. Daily fluctuations of inside air temperature for the room oriented to the south for various disturbances of solar heat gains for the duration of one day (a) and three days (b)

Taking into account the convenience to analyze the impact of factors disturbances in daily time intervals derived results were averaged for each day. Modelling results for outside air temperature, infiltration and heating rate disturbances impact on daily average inside air temperature are given in Figures 4-5. As opposed to solar radiation the values of the factors do not return to the base values. The disturbance impact on the indoor temperature depends on its value and has a remaining effect up to 10 days. 


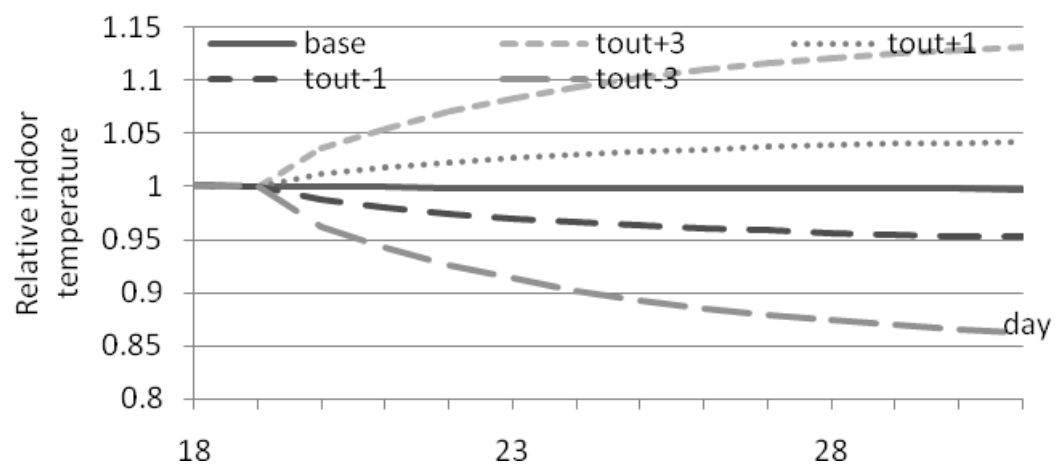

Figure 4. Daily average inside air temperature for different outside air temperature disturbances

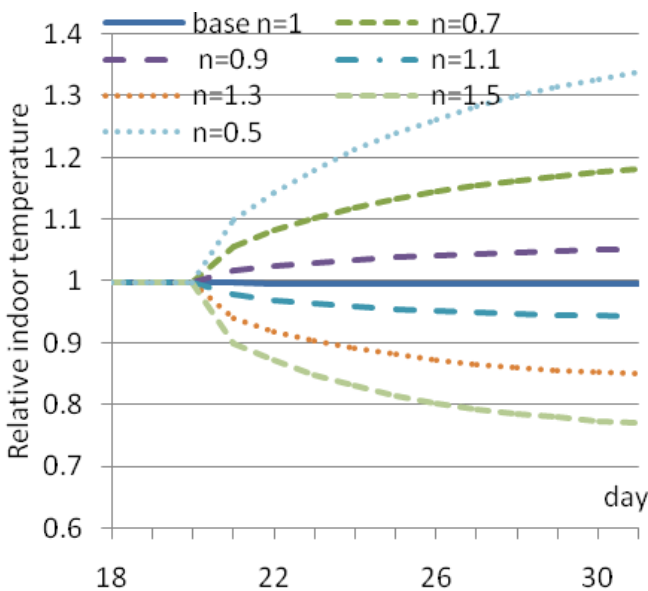

a)

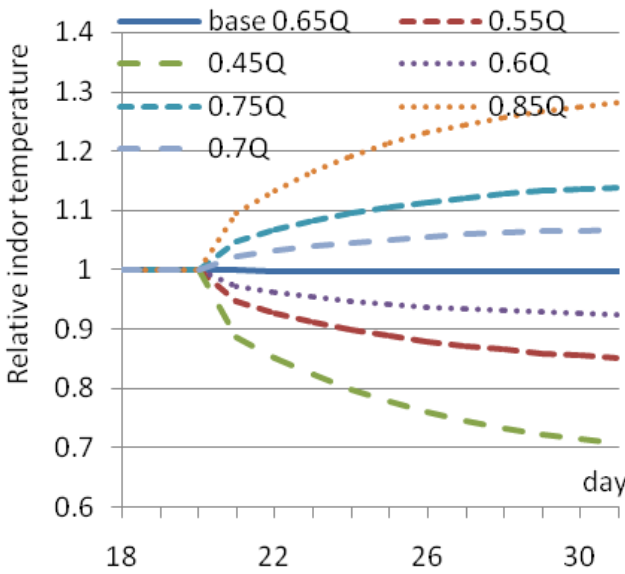

b)

Figure 5. Daily average inside air temperature for different infiltration (a) and heating rate (b) disturbances

It should be noted that daily average inside air temperature curves for symmetric disturbances of infiltration rate do not behave symmetrically with respect to the baseline. Analysis of simulation results shows that prehistory of influencing factors should be taken into consideration for correct estimation of indoor air temperature.

\section{Creation of regression model}

Linear multiple regression model built on the base of least square technique is used to predict daily average inside air temperature for different values of influencing factors. Non linear time effect is included by using difference of factors values for different days. Values normalization for regression model was performed for given ranges of factors: outside air temperature $\Delta t_{\text {out }}=13^{\circ} \mathrm{C}$, inside air temperature $\Delta \mathrm{t}_{\mathrm{in}}=12^{\circ} \mathrm{C}$, infiltration rate $\Delta \mathrm{n}=1.5$ hour $^{-1}$, heating rate $\Delta \mathrm{Q}=900 \mathrm{~W}$, solar heat gains $\Delta \mathrm{Q}_{\mathrm{sol}}=1000 \mathrm{~W}$.

Prehistory of factors analysis is carried out for outside air temperature change, from 1 to 5 prehistory days analysis is given. Difference of outside air temperature values for adjacent days is used in the regression models. The equation that includes 5-day history of the factor gives the most precise results of indoor air temperature comparing to dynamic simulation data. If the number of prehistory days is decreased to one, regression results greatly deviates from the curve of daily average inside air temperature from simulation modelling $(1-2 \stackrel{\circ}{\circ})$. That is why the regression model that includes 3 -day prehistory of the factor is considered in the paper, which provides sufficient accuracy of inside air temperature prognosis. Figure 6 gives prognostic values of temperature inside the zone depending on disturbances of outside air temperature for December from IWEC using 3-day prehistory regression model. As the model can be used for several days' temperature prediction, 1-day and 3-day prognosis values are given versus modelling results. 


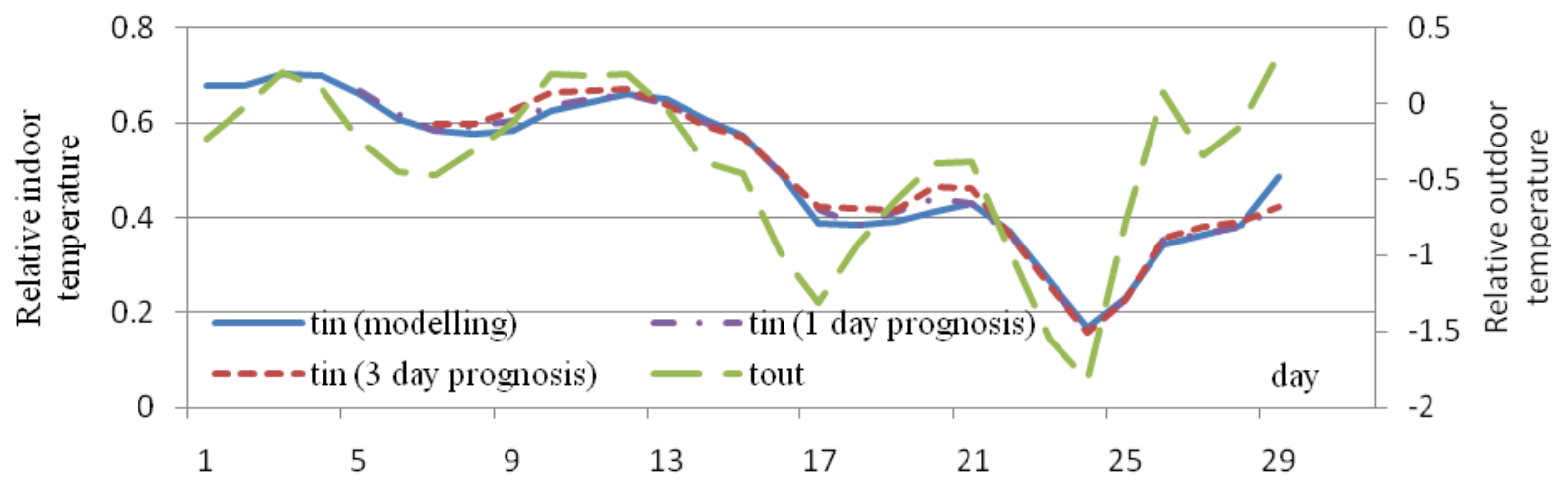

Figure 6. Prognostic values of inside air temperature depending on disturbances of outside air temperature

Regression models that include the background of factors change over the past three days and inside air temperature for the previous day can be written as follows:

- for outside air temperatures

$$
\begin{gathered}
t_{\text {in.i }}=-0.03242+1.05734 t_{\text {in.i-1 }}+0.2519\left(t_{\text {out.i }}-t_{\text {out.i-1 }}\right)+0.11633\left(t_{\text {out.i-1 }}-t_{\text {out. }-2-2}\right)+ \\
+0.08283\left(t_{\text {out.i-2 }}-t_{\text {out. }-3-3}\right), \\
R_{\text {adj }}^{2}=0.99854,
\end{gathered}
$$

- for solar heat gains

$$
\begin{aligned}
& t_{\text {in.i }}=-0.04384+1.07479 t_{\text {in.i- } 1}+0.12189\left(Q_{\text {sol.i }}-Q_{\text {sol. } i-1}\right)+0.14401\left(Q_{\text {sol. } i-1}-Q_{\text {sol.i- }-2}\right)+ \\
& +0.0911\left(Q_{\text {sol.i-2 }}-Q_{\text {sol.i-3 }}\right) \text {, } \\
& R_{\text {adj }}^{2}=0.96085 \text {, }
\end{aligned}
$$

- for infiltration rate

$$
\begin{gathered}
t_{\mathrm{in.i}}=-0.02657+1.05784 t_{\mathrm{in. \textrm {i } - 1}-0.41018\left(n_{\mathrm{i}}-n_{\mathrm{i}-1}\right)-0.16468\left(n_{\mathrm{i}-1}-n_{\mathrm{i}-2}\right)-}^{-} \\
-0.10165\left(n_{\mathrm{i}-2}-n_{\mathrm{i}-3}\right), \\
R_{\text {adj }}^{2}=0.99679,
\end{gathered}
$$

- for heating rate

$$
\begin{gathered}
t_{\text {in.i }}=-0.05587+1.106 t_{\text {in. }-1}+0.34094\left(Q_{\mathrm{i}}-Q_{\mathrm{i}-1}\right)+0.0854\left(Q_{\mathrm{i}-1}-Q_{\mathrm{i}-2}\right)+ \\
+0.04943\left(Q_{\mathrm{i}-2}-Q_{\mathrm{i}-3}\right), \\
R_{\text {adj }}^{2}=0.99912,
\end{gathered}
$$

where i - day number; $t_{\text {in }}$ - daily average inside air temperature; tout - daily average outside air temperature; $\mathrm{Qsol}_{\mathrm{sol}}$ - daily average solar heat gains; $\mathrm{Q}$ - heating rate; $\mathrm{n}$ - infiltration rate.

The processing of calculation results for individual factors influence on daily average inside air temperature using multiple linear regression models provides adjusted coefficient of determination value $R_{\mathrm{adj}}^{2}$ above 0.99 , with the exception of solar heat gains influence, where $R_{\mathrm{adj}}^{2}$ is equal to 0.96 . follows:

The overall regression model that takes into account all the influencing factors can be written as

$$
\begin{aligned}
& t_{\text {in.i }}=-0.03123+1.05865 t_{\text {in.i-1 }}+0.25119\left(t_{\text {out.i }}-t_{\text {out. }-1-1}\right)+0.11633\left(t_{\text {out.i-1 }}-t_{\text {out.i-2 } 2}\right)+ \\
& +0.08283\left(t_{\text {out.i }-2}-t_{\text {out.i-3 }}\right)-0.41018\left(n_{\mathrm{i}}-n_{\mathrm{i}-1}\right)-0.16435\left(n_{\mathrm{i}-1}-n_{\mathrm{i}-2}\right)-0.10117\left(n_{\mathrm{i}-2}-n_{\mathrm{i}-3}\right)+ \\
& +0.11864\left(Q_{\text {sol.i }}-Q_{\text {sol.i-1 }}\right)+0.14158\left(Q_{\text {sol.i- } 1}-Q_{\text {sol.i-2 }-2}\right)+0.0904\left(Q_{\text {sol.i-2 }}-Q_{\text {sol.i-3 }}\right)+ \\
& +0.34094\left(Q_{\mathrm{i}}-Q_{\mathrm{i}-1}\right)+0.10154\left(Q_{\mathrm{i}-1}-Q_{\mathrm{i}-2}\right)+0.07133\left(Q_{\mathrm{i}-2}-Q_{\mathrm{i}-3}\right),
\end{aligned}
$$

The processing of general calculation results for individual factors influence using the latter equation provides $R_{\mathrm{adj}}^{2}$ value equal to 0.994 . Other characteristics for assessing the adequacy of regression model are the average approximation error $\bar{\varepsilon}=0,45 \%$ and standard error $\sigma_{0}=0.013$.

The comparison of prognosis values of inside air temperature using the last of the proposed regression model with modelling results for December weather data from IWEC is given in Figure 7 . The proposed regression models describe the change in average daily internal air temperature with standard deviation equal to $0.6 \stackrel{\circ}{\circ}$.

Белоус И.Ю., Дешко В.И., Сухогуб И.О. Параметрический анализ внутренней температуры воздуха здания // Инженерно-строительный журнал. 2016. № 8(68). С. 65-75. 


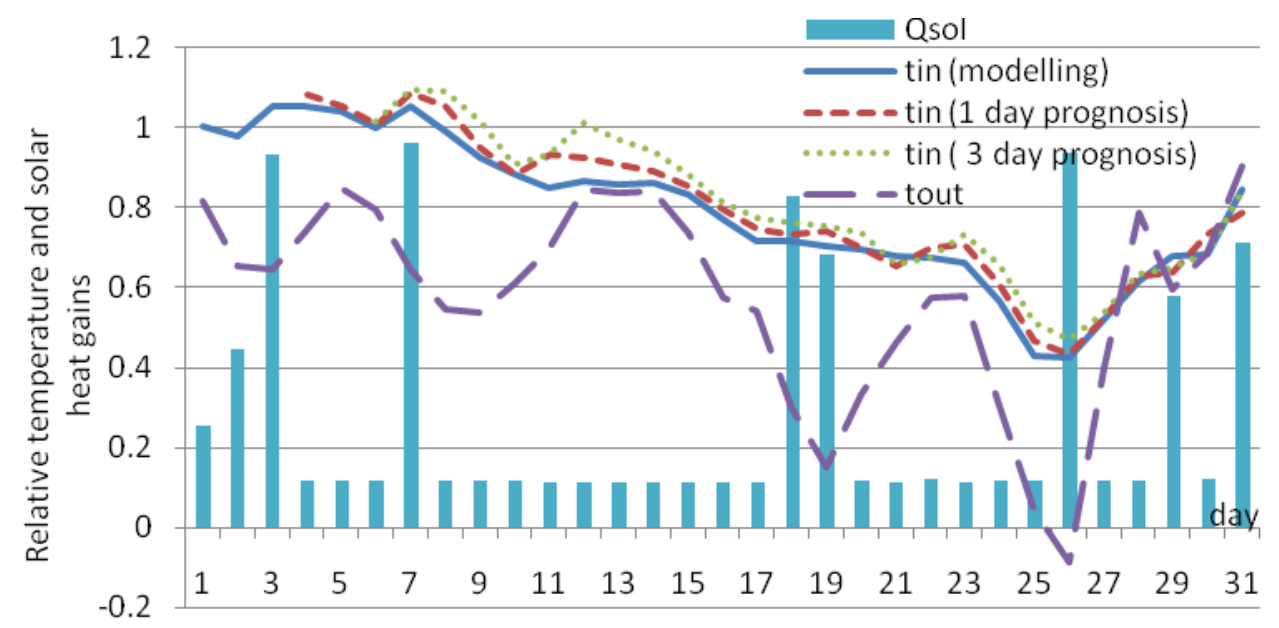

\section{Figure 7. Prognosis values of inside air temperature for December weather data}

The majority of existing heating system control methods is based on inside air temperature regulation; therefore it was used as desired parameter for regression models. At the same time EnergyPlus calculates operative temperature (that combines inside air temperature and mean radiant temperature). Further development of proposed regression models based on EnergyPlus simulation results can include investigation of operative temperature depending on influencing factors. This approach provides the analysis of internal and external factors influence on human thermal comfort [40].

\section{Conclusions}

Developed dynamic model based on EnergyPlus and modified IWEC weather data are used for the research of individual and aggregate factors influence on inside air temperature change. The regression model structure is analysed and background of factors change over the past three days is chosen. The possibility of using the proposed regression model for several day prognoses of daily average inside air temperature is considered.

Such regression models can be used for the following tasks:

1. selection and prognosis of heating rate in the room at a constant internal temperature and change of external factors;

2. assessment of internal temperature change at fixed and variable values of heating rate and changing external conditions;

3. assessment of internal temperature change at values of heating rate depending on outside air temperature taking into account change of external factors.

\section{References}

1. Malyarenko V.A., Orlova N.A. Analiz kriteriya energoeffektivnosti zdaniy i sooruzheniya [Analysis of the criterion of energy efficiency of buildings and structures. Integrovani tekhnologiï ta yenergozberezhennya. 2004. No. 2. Pp. 43-48. (ua)

2. Tabunshchikov Yu.A. Broda M.M. Matematicheskoye modelirovaniye i optimizatsiya teplovoy effektivnosti zdaniy [Mathematical modeling and optimization of thermal efficiency of buildings]. Moscow: AVOK-PRES, 2002. 194 p. (rus)

3. Bogoslovskiy V.N. Teplovoy rezhim zdaniya [Building thermal behavior]. Moscow: Stroyizdat, 1979. 248 p. (rus)

4. DBN V.2.6 31:2006. Konstruktsiï budinkiv ta sporud. Teplova izolyatsiya budivel [Ukrainian State Building Codes V.2.6_31:2006. Construction of buildings and structures. Insulation of buildings]. Kiev: Minbud Ukraïni. 2006. (ua)

5. DSTU B EN ISO 13790:2011. Yenergoyefektivnist budivel. Rozrakhunok yenergospozhivannya pri opalenni ta okholodzhenni [National Standard of Ukraine DSTU B EN ISO 13790:2011. Energy efficiency of buildings. Calculation of energy consumption for heating and cooling]. Kiev:

\section{Литература}

1. Маляренко В.А., Орлова Н.А. Анализ критерия энергоэффективности зданий и сооружения // Інтегровані технології та енергозбереження. 2004. № 2. C. $43-48$.

2. Табунщиков Ю.А., Брода М.М. Математическое моделирование и оптимизация тепловой эффективности зданий. М.: АВОК-ПРЕС, 2002. 194 с.

3. Богословский В.Н. Тепловой режим здания. М.: Стройиздат, 1979. 248 с.

4. ДБН В.2.6_31:2006. Конструкції будинків та споруд. Теплова ізоляція будівель. К.: Мінбуд України. 2006.

5. ДСТУ Б EN ISO 13790:2011. Енергоефективність будівель. Розрахунок енергоспоживання при опаленні та охолодженні. К.: НДІБК, 2011.

6. Mijakowski M., Narowski P., Sowa J. Integrated calculations of thermal behaviour of buildings and processes in AHU the tool for assessment of energy performance of complex buildings // Building Simulation. 2009. Pp. 875-882.

7. Gendelis S., Jakovics A. Influence of solar radiation and ventilation conditions on heat balance and thermal comfort conditions in living-rooms. [Электронный ресурc].

Bilous I.Yu., Deshko V.I., Sukhodub I.O. Building inside air temperature parametric study. Magazine of Civil Engineering. 2016. No. 8. Pp. 65-75. doi: 10.5862/MCE.68.7 
NDIBK, 2011. (ua)

6. Mijakowski M., Narowski P., Sowa J. Integrated calculations of thermal behaviour of buildings and processes in AHU the tool for assessment of energy performance of complex buildings. Building Simulation. 2009. Pp. 875-882.

7. Gendelis S., Jakovics A. Influence of solar radiation and ventilation conditions on heat balance and thermal comfort conditions in living-rooms [Electronic resourse]. System requirements: AdopeAcrobatReader. URL: http://www.modlab.Iv/publications/2007/BHTC-2-634.pdf

8. Deshko V.I., Bilous I.Yu. Matematichni modeli budivel dlya otsinki yenergospozhivannya [Mathematical models for assessing energy buildings]. Budivelni konstruktsii: Mizhvidomchiy naukovo-tekhnichniy zbirnik naukovikh prats (budivnitstvo). 2014. No. 80. Pp. 68-72. (ua)

9. Tronchin L., Fabbri K. Energy performance building evaluation in Mediterranean countries: Comparison between software simulations and operating rating simulation. Energy and Buildings. 2008. No. 40. Pp. 1176-1187.

10. Ko Y.-S., No S.T. A study on comparison of building energy simulation and measurement results for a city hall. Journal of Building Construction and Planning Research. 2015. No. 3. Pp. 1-9.

11. Rallapalli H.S. A Comparison of EnergyPlus and eQUEST Whole Building Energy Simulation Results for a Medium Sized Office Building. Master Thesis. Arizona State University. 2010. Pp. 84.

12. Abdullah A., Cross B., Aksamija A. Whole building energy analysis: a comparative study of different simulation tools and applications in architectural design. ACEEE Summer Study on Energy Efficiency in Buildings. 2014. Pp. 11-1 11-12

13. Attia S., Hensen J.L.M., Bertran L., De Herde A.Selection criteria for building performance simulation tools: contrasting architects' and engineers' needs. Journal of Building Performance Simulation. 2012. No. 5(3). Pp. 155-169.

14. Official EnergyPlus webside. [Electronic resourse]. URL: https://energyplus.net/

15. Crawley D.B., Lawrie L.K., Winkelmann F.C., Buhl W.F., Huang Y.J., Pedersen C.O., Strand R.K., Liesen R.J., Fisher D.E., Wittef M.J., Glazer J. EnergyPlus: creating a new-generation building energy simulation program. Energy and Buildings. 2001. No. 33. Pp. 319-331.

16. Crawley D.B., Winkelmann F.C., Lawrie L.K., Pedersen C.O. EnergyPlus: new capabilities in a whole-building energy simulation program. 7th International IBPSA Conference, Rio de Janeiro, Brazil. 2001. Pp. 51-58.

17. Liang X., Wang Y., Roskilly T. Reduce household energy consumption using passive methods. Energy Procedia. 2015. No. 75. Pp. 1335-1340.

18. Wasilowski H., Christoph R. Modelling an existing building in design builder/energyplus: custom versus default inputs. 11th International IBPSA Conference Glasgow, Scotland. 2009. Pp. 1252-1259.

19. Monfet D., Zmeureanu R., Charneux R., Lemire N. Computer model of a university building using the energyplus program. Building and Environment Journal. 2007.

20. Winkelmann F.C. Modeling windows in energyplus. 7th International IBPSA Conference Rio de Janeiro, Brazil. 2001. Building Simulation. Pp. 457-464.

21. Korniyenko S.V., Vatin N.I., Gorshkov A.S. Thermophysical field testing of residential buildings made of autoclaved aerated concrete blocks. Magazine of Civil Engineering.. 2016. No. 4(64). Pp. 10-25.

22. Fumo N., Mago P., Luck R. Methodology to estimate building energy consumption using EnergyPlus Benchmark Models. Energy and Buildings. 2010. No. 42. Pp. 23312337.

23. Neto A.H., Flar'vio Augusto Sanzovo Fiorelli Comparison
Сист.требования: AdopeAcrobatReader. URL: http://www.modlab.lv/publications/2007/BHTC-2-634.pdf

8. Дешко В.І., Білоус І.Ю. Математичні моделі будівель для оцінки енергоспоживання // Будівельні конструкції: Міжвідомчий науково-технічний збірник наукових праць (будівництво). 2014. № 80. С. 68-72.

9. Tronchin L., Fabbri K. Energy performance building evaluation in Mediterranean countries: Comparison between software simulations and operating rating simulation // Energy and Buildings. 2008. № 40. Pp. 1176-1187.

10. Ko Y.-S., No S.T. A study on comparison of building energy simulation and measurement results for a city hall // Journal of Building Construction and Planning Research. 2015. № 3. Pp. 1-9.

11. Rallapalli H.S. A Comparison of EnergyPlus and eQUEST Whole Building Energy Simulation Results for a Medium Sized Office Building // Master Thesis. Arizona State University. 2010. Pp. 84.

12. Abdullah A., Cross B., Aksamija A. Whole building energy analysis: A comparative study of different simulation tools and applications in architectural design // ACEEE Summer Study on Energy Efficiency in Buildings. 2014. Pp. 11-1-1112

13. Attia S., Hensen J.L.M., Bertran L., De Herde A. Selection criteria for building performance simulation tools: contrasting architects' and engineers' needs // Journal of Building Performance Simulation. 2012. № 5(3). Pp. 155-169.

14. Официальный веб-сайт EnergyPlus [Электронный pecypc]. URL: https://energyplus.net/

15. Crawley D.B., Lawrie L.K., Winkelmann F.C., Buhl W.F., Huang Y.J., Pedersen C.O., Strand R.K., Liesen R.J., Fisher D.E., Wittef M.J., Glazer J. EnergyPlus: creating a new-generation building energy simulation program // Energy and Buildings. 2001. № 33. Pp. 319-331.

16. Crawley D.B., Winkelmann F.C., Lawrie L.K., Pedersen C.O. EnergyPlus: new capabilities in a whole-building energy simulation program. // 7th International IBPSA Conference, Rio de Janeiro, Brazil, 2001. Pp. 51-58

17. Liang X., Wang Y., Roskilly T. Reduce household energy consumption using passive methods // Energy Procedia. 2015. № 75. Pp. 1335-1340.

18. Wasilowski H., Christoph R. Modelling an existing building in design builder/energyplus: custom versus default inputs // 11th International IBPSA Conference Glasgow, Scotland, 2009. Pp. 1252-1259.

19. Monfet D., Zmeureanu R., Charneux R., Lemire N. Computer model of a university building using the energyplus program // Building and Environment Journal, 2007.

20. Winkelmann F.C. Modeling windows in energyplus // 7th International IBPSA Conference Rio de Janeiro, Brazil, 2001. Building Simulation. Pp. 457-464.

21. Корниенко С.В., Ватин Н.И., Горшков А.С. Натурные теплофизические испытания жилых зданий из газобетонных блоков // Инженерно-строительный журнал. 2016. № 4(64). С. 10-25

22. Fumo N., Mago P., Luck R. Methodology to estimate building energy consumption using EnergyPlus Benchmark Models // Energy and Buildings. 2010. № 42. Pp. 23312337.

23. Neto A.H., Flar vio Augusto Sanzovo Fiorelli Comparison between detailed model simulation and artificial neural network for forecasting building energy consumption /I Energy and Buildings. 2008. № 40. Pp. 2169-2176.

24. Lau H.C.W., Cheng E.N.M., Lee C.K.M., Ho G.T.S. A fuzzy logic approach to forecast energy consumption change in a manufacturing system // Expert Systems with Applications. 2008. № 34. Pp. 1813-1824.

25. Ciabattoni L., Grisostomi M., Ippoliti G., Longhi S. Fuzzy logic home energy consumption modeling for residential

Белоус И.Ю., Дешко В.И., Сухогуб И.О. Параметрический анализ внутренней температуры воздуха здания // Инженерно-строительный журнал. 2016. № 8(68). С. 65-75. 
between detailed model simulation and artificial neural network for forecasting building energy consumption. Energy and Buildings. 2008. No. 40. Pp. 2169-2176.

24. Lau H.C.W., Cheng E.N.M., Lee C.K.M., Ho G.T.S. A fuzzy logic approach to forecast energy consumption change in a manufacturing system. Expert Systems with Applications. 2008. No. 34. Pp. 1813-1824.

25. Ciabattoni L., Grisostomi M., Ippoliti G., Longhi S. Fuzzy logic home energy consumption modeling for residential photovoltaic plant sizing in the new Italian scenario. Energy. 2014. No. 74. Pp. 359-397.

26. Song F., Jiang Y., Mouel A. L.,. Roux J.-J.Development of a data model for consumption analysis and prediction of larsescale commercial building. Building Simulation. 2007. Pp. 1601-1609.

27. Popescu D., Ungureanu F., Serban E. Simulation of Consumption in District Heating Systems. Environmental problems and development, Bucharest, Romania. 2008. Pp. 50-55.

28. Aranda A., Ferreira G., Mainar-Toledo M.D., Scarpellini S. Sastresa E.L. Multiple regression models to predict the annual energy consumption in the Spanish banking sector. Energy and Buildings. 2012. No. 49. Pp. 380-387.

29. Afanasyev V.V., Kovalev V.G., Tarasov V.A., Tarasova V.V., Fedorov D.G. Issledovaniye raskhoda teplovoy energi na otopleniye zdaniy [The study of the consumption of heat energy for heating buildings]. Vestnik Chuvashskogo universiteta. 2014. No. 2. Pp. 10-18. (rus)

30. Deshko V.I., Bilous I.Yu. Monitoring temperaturnogo stanu navchalnogo korpusu [Monitoring temperature state schoo building]. Yenergetika: yekonomika, tekhnologiï, yekologiya. 2015. No. 2. Pp. 22-29. (ua)

31. Vinogradov A.N. Otsenka dostovernosti izmereniya temperatury $v$ sistemakh teplopotrebleniya $s$ ispolzovaniyem apparata regressionnogo analiza [Evaluation of the reliability of temperature measurement in heat consumption systems using the regression analysis apparatus]. Trudy Mezhdunarodnogo simpoziuma "Nadezhnost i kachestvo" [Proceedings of International academic conference]. 2006 No. 1. Pp. 326-328. (rus)

32. Chipulis V.P., Kuznetsov R.S. Analiz effektivnost regulirovaniya teplopotrebleniya $\mathrm{S}$ ispolzovaniyem regressionnykh modeley obyektov teploenergetiki [Analysis of the efficiency of heat consumption regulation using regression models of heat power facilities]. XII Vserossiyskoye soveshchaniye po problemam upravleniya VSPU [Russian meeting on the problems of WSPU management]. Moscow, 2014. Pp. 7529-7539. (rus)

33. Chipulis V.P. Otsenka effektivnosti regulirovaniya teplopotrebleniya $s$ ispolzovaniyem arkhivnoy informatsii priborov ucheta teplovoy energii [Estimation of the efficiency of heat consumption regulation using the archival information of heat energy meters]. Trudy Mezhdunarodnogo simpoziuma "Nadezhnost i kachestvo" [Proceedings of International academic conference]. 2013. No. 2. Pp. 273-277.

34. Westphal F. S., Lamberts R. Regression analysis of electric energy consumption of commercial buildings in Brazil. Proceedings: Building Simulation. 2007. Pp. 1543-1550.

35. Amiri S.S., Mottahedi M., Asadi S. Using multiple regression analysis to develop energy consumption indicators for commercial buildings in the U.S. Energy and Building. 2015 No. 109. Pp. 209-216.

36. Korolija I., Zhang Y., Marjanovic-Halburd L., Hanby V.I Regression models for predicting UK office building energy consumption from heating and cooling demands. Energy and Buildings. 2013. No. 59. Pp. 214-227.

37. DSTUB A.2.2-12:2015. Yenergetichna yefektivnist budivel. metod rozrakhunku yenergospozhivannya pri opalenni, okholodzhenni, ventilyatsiï, osvitlenni ta garyachomu vodopostachanni [National Standard of Ukraine DSTUB photovoltaic plant sizing in the new Italian scenario. // Energy. 2014. № 74. Pp. 359-397.

26. Song F., Jiang Y., Mouel A. L., Roux J.-J. Development of a data model for consumption analysis and prediction of larsescale commercial building. // Building Simulation. 2007. Pp. 1601-1609.

27. Popescu D., Ungureanu F., Serban E. Simulation of Consumption in District Heating Systems // Environmental problems and development, Bucharest, Romania, 2008. Pp. 50-55.

28. Aranda A., Ferreira G., Mainar-Toledo M.D., Scarpellini S., Sastresa E.L. Multiple regression models to predict the annual energy consumption in the Spanish banking sector. // Energy and Buildings. 2012. № 49. Pp. 380-387.

29. Афанасьев В.В., Ковалев В.Г., Тарасов В.А., Тарасова В.В., Федоров Д.Г. Исследование расхода тепловой энергии на отопление зданий // Вестник Чувашского университета. 2014. № 2. С. 10-18.

30. Дешко В.І., Білоус І.Ю. Моніторинг температурного стану навчального корпусу // Енергетика: економіка, технології, екологія. 2015. № 2. С. 22-29.

31. Виноградов А.Н. Оценка достоверности измерения температуры в системах теплопотребления с использованием аппарата регрессионного анализа // Труды Международного симпозиума «Надежность и качество». 2006. № 1. С. 326-328.

32. Чипулис В.П., Кузнецов Р.С. Анализ эффективности регулирования теплопотребления с использованием регрессионных моделей объектов теплоэнергетики // XII Всероссийское совещание по проблемам управления ВСПУ. Москва, 2014. С. 7529-7539.

33. Чипулис В.П. Оценка эффрективности регулирования теплопотребления с использованием архивной информации приборов учета тепловой энергии // Труды Международного симпозиума «Надежность и качество». 2013. № 2. C. 273-277.

34. Westphal F. S., Lamberts R. Regression analysis of electric energy consumption of commercial buildings in Brazil // Proceedings: Building Simulation. 2007. Pp. 1543-1550.

35. Amiri S.S., Mottahedi M., Asadi S. Using multiple regression analysis to develop energy consumption indicators for commercial buildings in the U.S // Energy and Buildings 2015. № 109. Pp. 209-216.

36. Korolija I., Zhang Y., Marjanovic-Halburd L., Hanby V.I. Regression models for predicting UK office building energy consumption from heating and cooling demands // Energy and Buildings. 2013. № 59. Pp. 214-227.

37. ДСТУБ А.2.2-12:2015. Енергетична ефективність будівель. метод розрахунку енергоспоживання при опаленні, охолодженні, вентиляції, освітленні та гарячому водопостачанні. К.: Мінрегіон України, 2015.

38. ДСТУ-Н Б В.1.1-27:2010. Будвельна кліматологія. К.: Мінрегіон України, 2010.

39. Walker I.S., Wilson D.J. Field validation of algebraic equations for stack and wind sriven air infiltration calculation // ASHRAE HVAC\&R Research Journal. 1998. № 2(4). Pp. 1-22.

40. Deshko V., Buyak N. A model of human thermal comfort for analysing the energy performance of buildings // EasternEuropean Journal of Enterprise Technologies. 2016. № 4/8(82). Pp. 42-48.

Bilous I.Yu., Deshko V.I., Sukhodub I.O. Building inside air temperature parametric study. Magazine of Civil Engineering. 2016. No. 8. Pp. 65-75. doi: 10.5862/MCE.68.7 
A.2.2-12:2015. The energy efficiency of buildings. method of calculating the energy consumption for heating, cooling, ventilation, lighting and hot water]. Kiev: Minregion Ukraïni, 2015. (ua)

38. DSTU-N B V.1.1-27:2010. Budvelna klimatologiya [National Standard of Ukraine DSTU-N B V.1.1-27:2010. Construction climatology]. Kiev: Minregion Ukraïni, 2010.

39. Walker I.S., Wilson D.J. Field validation of algebraic equations for stack and wind sriven air infiltration calculation. ASHRAE HVAC\&R Research Journal. 1998. No. 2(4). Pp. 1-22.

40. Deshko V., Buyak N. A model of human thermal comfort for analysing the energy performance of buildings. EasternEuropean Journal of Enterprise Technologies. 2016. No. 4/8(82). Pp. 42-48.

Inna Bilous,

+3(804)42049690; biloys_inna@ukr.net

Инна Юрьевна Белоус,

+3(804)42049690; эл. почma: biloys_inna@ukr.net

Valerij Deshko,

+380444068250; te@kpi.ua

Валерий Иванович Дешко,

+380444068250; эл. почта: te@kpi.ua

Iryna Sukhodub,

+380442049690; ira_krot@ukr.net

Ирина Олеговна Суходуб,

+380442049690; эл. почта: ira_krot@ukr.net

(C) Bilous I.Yu., Deshko V.I., Sukhodub I.O., 2016

Белоус И.Ю., Дешко В.И., Сухогуб И.О. Параметрический анализ внутренней температуры воздуха здания // Инженерно-строительный журнал. 2016. № 8(68). С. 65-75. 